\title{
Sociocultural Peculiarities of Dynamics of Migration Processes in Central Siberia (Exemplified by the Materials of Researches Conducted in the Krasnoyarsk Territory in 2010-2014)
}

\author{
Valentin G. Nemirovsky*a and Anna V. Nemirovskaya ${ }^{\mathrm{b}}$ \\ ${ }^{a}$ Siberian Federal University \\ 79 Svobodny, Krasnoyarsk, 660041, Russia \\ ${ }^{b}$ National Research University \\ "Higher School of Economics" \\ 20 Myasnitskaya, Moscow, 101000, Russia
}

Received 16.11.2015, received in revised form 07.01.2016, accepted 26.02.2016

Socio-cultural peculiarities of migration processes in one of the largest regions of Siberia - the Krasnoyarsk Territory are studied in the research paper. The research is based on the data of the survey of the Krasnoyarsk Territory population, conducted by semi-structured interview method according to the methodology of "Sociocultural Portrait of the Territory" in 2010, 2012 and 2014. The dynamics of emotional attitudes of the Territory residents in the context of their migratory moods and opinions on the quality of life in the Krasnoyarsk Territory, compared with other regions of Siberia, on the cultural aspects of attractiveness (and unattractiveness) of life in the Territory are revealed in the article. Increase in the negative attitudes of the Krasnoyarsk Territory population to the arriving migrants of other nationalities, associated, mainly, with the cultural antagonism has been revealed. This sociocultural situation is becoming more vivid at the behavioral level. The assumption of possible violation of the traditionally existed in the region tradition of multiculturalism in the future is made.

Keywords: sociocultural processes, sociocultural perceptions, cultural attractiveness of the region, sociocultural aspects of migration, multiculturalism.

DOI: 10.17516/1997-1370-2016-9-4-854-867.

Research area: sociology.

\section{Introduction}

One of the most significant sociocultural problems for the modern Siberia is migration, considered in the context of socio-cultural processes taking place in this macro-region. Under modern conditions the presence of distinct cultural and ethnic aspects, as well as the growing influence of specific cultural factors gives increased significance to their analysis. It should be noted that, in general, interrelation of sociocultural processes and migration is widely studied in modern Russian science. Thus, a

(C) Siberian Federal University. All rights reserved

* Corresponding author E-mail address: valnemirov@mail.ru 
number of dissertation researches (Chaban, 2006, Mukomel, 2006, et al.) and applied researches (Migrations..., 2010, Nemirovskiy, Nemirovskaya, 2010) are devoted to the analysis of these issues through the example of the Russian Federation. A considerable number of cultural studies are aimed at studying migration in Siberia macro-region (Koptseva et al.,2015, Popkov et al., 2016). For example, in the studies by N.P. Koptseva and Y.S. Zamaraeva this issue is considered through the example of Krasnoyarsk Territory, on the basis of the theoretical and methodological principles of the modern sociocultural approaches (Zamarayeva, 2011, Koptseva et al., 2016).

Alongside with that, the dynamics of migratory moods of the territory population, their sociocultural representations about such an essential factors of migration as the quality of life in the Krasnoyarsk Territory, compared with the other regions of Siberia, about deterrents to the region's population growth and about their attitudes toward arriving migrants remain understudied. Meanwhile, under conditions of financial and economic crisis in the country and the threat of international terrorism, the analysis of these issues is important. Moreover, it is important to use cultural approach to their study in the context of objective data on population migration in the Territory, which the state statistics provides.

The aim of this study is analysis of sociocultural aspects of the dynamics of migration processes in the Krasnoyarsk Territory.

To reach it the following objectives have been implemented:

1. The study of emotional attitude of the Territory residents in the context of their intentions to leave the Territory.

2. Identify the respondents' opinion about the quality of life in the Krasnoyarsk Territory, compared with other regions of Siberia.
3. Analysisoftherespondents' representations about the attractive and unattractive aspects of life in the Territory.

4. The study of statistical data characterizing the dynamics of migration processes in the Krasnoyarsk Territory.

5. Identify the Territory residents' opinions about the deterrents for the population growth in the Krasnoyarsk Territory.

6. The analysis of attitudes of the Krasnoyarsk Territory population towards the arriving migrants.

\section{Research Methods}

This article is based on the results of sociocultural studies conducted in 2010 - 2014 in the Krasnoyarsk Territory according to representative regional sampling in accordance with the Standard Programme and Methodology "Sociocultural Portrait of the Territory" of Centre for the Study of Social and Cultural Change of the Institute of Philosophy of the Russian Academy of Sciences (The Methodological..., 2009). Population surveys were carried out by the method of semi-structured interviews at the respondents' domicile, according to stratified, multi-stage, stratified and quota sampling represented by sex, age and the level of education, random at the stage of the respondents' selection. Representativeness of the sampling is provided by keeping proportions between the population living in the various types of settlements (city districts, medium-sized and small towns and rural-type settlements), sex and age and educational structure of the adult population of the Krasnoyarsk Territory.

1. In $2010, \mathrm{n}=1000$ respondents, the study was carried out with financial support from the Russian Humanitarian Science Foundation, project number 10-03-00001a "Peculiarities of Sociocultural Portrait of the Krasnoyarsk Territory". 
2. In $2012, \mathrm{n}=1300$ respondents, the study was carried out with financial support from the Russian Humanitarian Science Foundation, project number 11-03-00250a "Peculiarities of Social Structure and Social Capital Formation in the Krasnoyarsk Territory".

3. In 2014, $\mathrm{n}=1,000$ respondents, the study was carried out with financial support from the Russian Humanitarian Science Foundation, project number 13-03-00379a "The Dynamics of Sociocultural Processes in the East Siberian Region in the Context of the Contemporary Modernization of Russia (Through the Materials of Sociological Researches Conducted in the Krasnoyarsk Territory)".

4. The materials of state and departmental statistics that characterize the processes under study were used. It should be noted that due to the delay of the official publication of official statistical data, the latter, as a rule, are represented by 2014. In some cases, connected with their availability, the data from the previous years were used (Migration of ..., 2016, More than..., 2016, Nemirovskiy et al., 2014).

\section{Study Results}

Answering the question about the general emotional attitude to their region (Table 1), the majority of the respondents have chosen the answer "In general, I am satisfied, but not comfortable with many things" (46\% - 2010 $44 \%-2012,35 \%-2014)$.

For the period of 4 years the proportion of those, who answered "I am glad that I live here" slightly increased: 23.9, 21.9 and 30.6 $\%$ respectively. $12 \%$ in $2010,14 \%$ in 2012 and $15 \%$ in 2014 of the respondents demonstrated indifference to the Krasnoyarsk Territory. Every year about $6 \%$ of the surveyed residents of the Territory chose the answers "I don't like to live here, but I got used to it and not going to leave", as well as "I would like to move to another region of Russia". There was a slight tendency to growth in the number of residents who declared intention to leave Russia: $4.1 \%$ in $2010,6.3 \%$ in 2012 and in $7.0 \% 2014$.

Thus, it is possible to make a conclusion that both positive and critical residents' attitudes to their Territory has significantly increased. There is a kind of division of cultural orientations.

Opinions of the respondents from the Krasnoyarsk Territory on the quality of life in their region, compared with their representation of how people live in the neighboring regions of Siberia, has dramatically changed in the recent years (Table 2.): if in $20109.9 \%$ of the respondents chose the answer "In our region people live better than in the neighboring regions", in $2012-11.1 \%$, and in 2014 the number was 19.9\%.

Table 1. Distribution of Answers to the Question "What Are Your Feelings Towards the Krasnoyarsk Territory?" ( $\%$ from the number of respondents)

\begin{tabular}{|l|c|c|c|}
\hline \multicolumn{1}{|c|}{ Variants of answers } & 2010 & 2012 & 2014 \\
\hline I am glad that I live here & 23,9 & 21,9 & 30,6 \\
\hline In general, I am satisfied, but not comfortable with many things & 46,1 & 43,9 & 35,3 \\
\hline I don't have special feelings in this regard & 12,2 & 14,0 & 14,7 \\
\hline I don't like to live here, but I got used to it and not going to leave & 5,3 & 6,5 & 5,5 \\
\hline I would like to move to another region of Russia & 6,4 & 6,6 & 5,6 \\
\hline I would like to move from Russia & 4,1 & 6,3 & 7,0 \\
\hline Cannot say & 2,0 & 0,8 & 1,3 \\
\hline
\end{tabular}


Table 2. Opinions of the Krasnoyarsk Territory Residents About life in the Territory and in the Neighboring Regions (\% from the number of respondents)

\begin{tabular}{|l|c|c|c|}
\hline \multicolumn{1}{|c|}{ Variants of answers } & 2010 & 2012 & 2014 \\
\hline In our region people live better than in the neighboring regions & 9,9 & 11,1 & 19,9 \\
\hline $\begin{array}{l}\text { Compared with some regions, people in our region live better, and } \\
\text { compared with others - worse }\end{array}$ & 62,3 & 58,7 & 57,7 \\
\hline In our region people live worse than in all the neighboring regions & 9,1 & 12,2 & 9,8 \\
\hline Cannot say & 18,7 & 18,0 & 12,6 \\
\hline
\end{tabular}

Table 3. Opinions of the Krasnoyarsk Territory Residents about Specific Characteristics of the Territory, its Attractive and Unattractive Features (\% from the number of respondents, more than one variant of answer is possible)

\begin{tabular}{|l|c|c|c|}
\hline \multicolumn{1}{|c|}{ Attractive features } & 2010 & 2012 & 2014 \\
\hline Beautiful nature & 83,8 & 81,9 & 78,8 \\
\hline Good and heartful people & 18,4 & 23,1 & 29,5 \\
\hline It is a region with good prospects for life & 23,0 & 18,3 & 21,2 \\
\hline There are a lot of opportunities here for enterprising people & 15,2 & 13,4 & 19,7 \\
\hline Other & 3,1 & 2,6 & 0,7 \\
\hline Cannot say & 4,7 & 7,7 & 4,5 \\
\hline Refuse to answer & 0,7 & 0,1 & 0,4 \\
\hline
\end{tabular}

The proportion of people who chose an ambiguous answer "Compared with some regions, people in our region live better, and compared with others - worse" has slightly decreased $(62.3 \%$ in $2010,58.7 \%$ in 2012 and $57.7 \%$ in 2014). At that, the proportion of the respondents who hold the opposite position - "In our region people live worse than in all the neighboring regions" has not changed. Therefore, more than a half of the Territory residents continue to hold neutral position.

To clarify the respondents' position regarding advantages and disadvantages of life in the Krasnoyarsk Territory their answers to the question: "What, in your experience, are the specific characteristics of our region, its attractive and unattractive features?" were used (Tables 3 and Tables 4).
An attractive feature that dominates in the mass consciousness of the Krasnoyarsk Territory residents is "Beautiful nature" - this variant of answer was supported by $84 \%$ of the respondents in $2010,82 \%$ in 2012 and $79 \%$ in 2014. In 2010 $23.0 \%$ of the respondents hold the opinion that the Krasnoyarsk Territory is "A region with good prospects for life", in $2012-18.3 \%$, and in $2014-21.2 \%$. The proportion of the respondents who answered that "Good and heartful people" live in the region has dramatically increased: from $18.4 \%$ in 2010 to $23.1 \%$ in 2012 and to $29.5 \%$ in 2014 . The number of respondents who believe that there are a lot of opportunities here for enterprising people (Table 3) has slightly increased.

Unattractive features of the Krasnoyarsk Territory that dominate in the mass consciousness of its residents, despite specific and ambiguous 
changes in these ideas that took place in $2010-$ 2014, have the same hierarchy: "The climate is too harsh" - $48.1 \%$, "Life has stalled here" $23.9 \%$ and "Unfriendly people" - 19.3\%. These three variants of answers are the most common (Table. 4).

According to the data obtained, the respondents give contradictory assessments to their fellow countrymen, on the one hand, the largest number of the respondents answered that good and heartful people live in the Territory (18.4\% in 2010 and $29.5 \%$ in 2014), on the other - the proportion of those who believe that unfriendly people is an unattractive feature of the Krasnoyarsk Territory has also increased (16.3\% in 2010 and $19.3 \%$ in 2014). Similarly, there is $4 \%$ increase in the number of those who mentioned "opportunities for enterprising people", but there was 3\% increase in the number of respondents who answered that "They don't like initiative" in the region.

In assessing the migration situation in the region, it is important to consider demographic challenges facing the region. Depopulation, high mortality rate, low birth rate and ageing population are the factors of the region's need in migrants, as economic development requires more work force and active population of working age. In the postSoviet period there was population decline in the
Krasnoyarsk Territory, it reached its peak in 2000 and repeated the nationwide trend till 2009. If in the period from 2000 to 2008 natural population growth in the Krasnoyarsk Territory was negative, in 2009 and 2010 the values were slightly positive with an increase in the coefficient values up to 1.7 in 2013 and 2014 (Fig. 1).

The respondents' representations about deterrents to population growth in the Krasnoyarsk Territory (Table 5) in 2014, compared with 2010, have significantly changed. Among the main deterrents to population growth in the Krasnoyarsk Territory in $201065.3 \%$ of the respondents mentioned "Low income", in $2012-65.7 \%$ and in $2010-56.3 \%$; "Poor living conditions" 41.2, 42.5 and $32.0 \%$ respectively, "The state practically does not provide material support to families with children" - 29.3, 28.8 and $34.4 \%$; "A lot of people believe that these days a child is enough" - 25.2, 28.2 and $32.5 \%$, "Poor medical care for women during pregnancy and in the process of childbirth" $-4.6,5.0$ and 5, 8\% (see Table 5). And only 5.0\% (2014) of the respondents believe that "Nothing prevents population growth in our Territory" (in 2010 the number of such responses constituted $2.6 \%$ and in $2012-5.8 \%$ ).

As we can see, the number of respondents who believe that low income of parents and poor

Table 4. Opinions of the Krasnoyarsk Territory Residents about Specific Characteristics of the Territory, its Attractive and Unattractive Features (\% from the number of respondents, more than one variant of answer is possible)

\begin{tabular}{|l|c|c|c|}
\hline \multicolumn{1}{|c|}{ Unattractive features } & 2010 & 2012 & 2014 \\
\hline The climate is too harsh & 54,8 & 42,9 & 48,1 \\
\hline Unfriendly people & 16,3 & 14,6 & 19,3 \\
\hline Life has stalled here & 23,8 & 31,7 & 23,9 \\
\hline They don't like initiative here & 9,0 & 14,3 & 12,3 \\
\hline Other & 6,7 & 8,5 & 4,1 \\
\hline Cannot say & 16,1 & 16,5 & 19,9 \\
\hline Refuse to answer & 6,2 & 0,1 & 0,3 \\
\hline
\end{tabular}




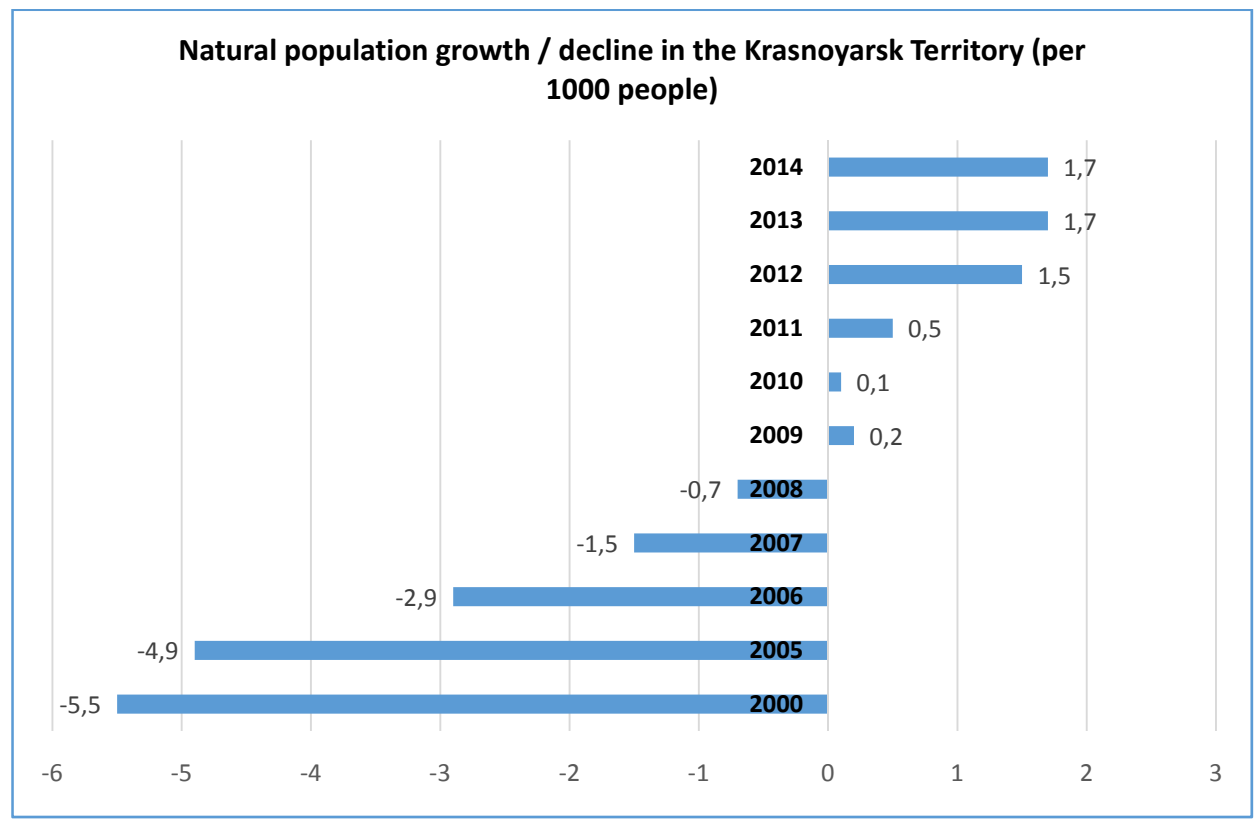

Fig. 1

Source: Natural Population Movement in the Krasnoyarsk Territory in The Krasnoyarsk Territory in Numbers. 2010 - 2015. A Statistical Yearbook. Krasnoyarsk State Statistical Office. Available at: http://krasstat.gks.ru/wps/wcm/connect/rosstat_ts/ krasstat/ru/publications/official_publications/electronic_versions/ (Accessed 10 January 2016)

Table 5. Residents About Deterrents to Population Growth in the Krasnoyarsk Territory (in \% o from the number of respondents)

\begin{tabular}{|l|c|c|c|}
\hline \multicolumn{1}{|c|}{ Variants of answers * } & 2010 & 2012 & 2014 \\
\hline A lot of people believe that these days a child is enough & 25,2 & 28,2 & 32,5 \\
\hline $\begin{array}{l}\text { The state practically does not provide material support to families with } \\
\text { children }\end{array}$ & 29,3 & 28,8 & 34,4 \\
\hline Poor living conditions & 41,2 & 42,5 & 32,0 \\
\hline Low income & 65,7 & 65,3 & 56,3 \\
\hline $\begin{array}{l}\text { Poor medical care for women during pregnancy and in the process of } \\
\text { delivery }\end{array}$ & 4,6 & 5,0 & 5,8 \\
\hline Other & 1,6 & 2,4 & 1,3 \\
\hline Nothing prevents population growth in our Territory & 2,6 & 1,4 & 5,0 \\
\hline Cannot say & 3,9 & 2,9 & 4,0 \\
\hline Refuse to answer & 0,9 & 0,8 & 0 \\
\hline * it is allowed to choose not more than two deterrents & & & \\
\hline
\end{tabular}

living conditions prevent childbirth has decreased. Along with that, the number of people who hold the opinion that one child is enough, and virtual absence of material support to families with children have increased.
At the same time, if we look at the natural population growth in the Territory in absolute rates, it is noticeable that in the last two years it is leveled by outgoing migration from the Krasnoyarsk Territory to the other regions 


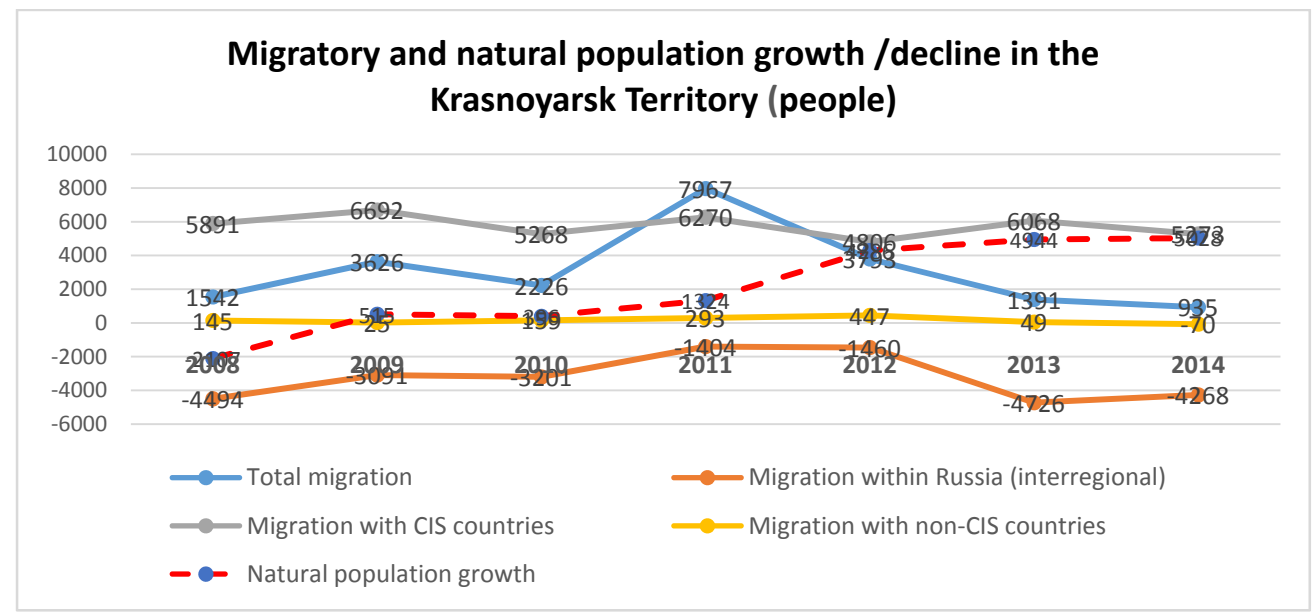

Fig. 2

Source: Total Results of Migration in the Krasnoyarsk Territory in The Krasnoyarsk Territory in Numbers. 2010 - 2015. A Statistical Yearbook. Krasnoyarsk State Statistical Office. Available at: http://krasstat.gks.ru/wps/wcm/connect/rosstat_ts/ $\mathrm{krasstat} / \mathrm{ru} /$ publications/official_publications/electronic_versions/ (Accessed 10 January 2016)

of the country (Fig. 2). In general, migration gain, reaching its peak in the period under consideration in 2011, had dramatic drop due to significant increase of interregional migration, since migration rates with the CIS countries, slightly fluctuating from year to year, remained approximately at the same level from 2008 to 2014 , every year overlapping outgoing migration of the population from the Krasnoyarsk Territory to other parts of the country (ibid). Migration with non-CIS countries was low over these years, however, until 2014 it had positive value, i.e. there was migrant influx to the region from non-CIS countries, but in 2014 this migratory movement changed its direction.

In 2014, regional center experienced the largest migration gain (12,121 people), followed far behind by Sosnovoborsk (1404 people) and Beryozovsky district (733 people). The largest population outflow took place from the territories of the Far North: from Norilsk (2038 people), Taymyr Dolgan-Nenets district (705 people) and eastern part of the region - Nizhneingashsky and Abansky districts (593 and 534 people) (Migration of ..., 2016).
As a result of interregional migration processes in 2014, migration outflow of the population (4 268 people) was registered in the Krasnoyarsk Territory (Fig. 2). 36425 migrants arrived to the Krasnoyarsk Territory from other regions of Russia. The largest migrant influx was registered from the regions of Siberian, Central and Volga Federal Districts of the Russian Federation - 19572 people, 3429 people and 3 212 people correspondingly. 40693 people moved to other regions of Russia from the Krasnoyarsk Territory. The largest number of migrants moved to the regions of the Siberian, Central and Southern federal districts - 15750 people, 6850 people and 4759 people correspondingly (Migration of ..., 2016).

Thus, the decline of the Territory population due to interregional migration exchange was 4 268 people. As a result of international migration processes in the Krasnoyarsk Territory, population growth (5 203 people) was registered (Fig. 2). 8 365 people immigrated to the Territory from the CIS countries, the largest number of migrants came from Tajikistan (1 912 people), Ukraine (1 260) and Kazakhstan (1 218 people). 3092 
people moved from the Krasnoyarsk Territory to the CIS countries, the largest number of migrants moved to Kazakhstan (597 people), Uzbekistan (576 people) and Tajikistan (556 people). 721 people immigrated to the Territory from non-CIS countries, the largest number of migrants arrived from China (254 people), Georgia (133 people) and Germany (91 people). 791 people immigrated to non-CIS countries, the largest number moved to China (214 people), Germany (101 people) and Turkey (55 people) (Migration of ..., 2016).

As well as a number of other regions of the Siberian Federal District, the Krasnoyarsk Territory is experiencing a shortage of workforce, including low-skilled. It is compensated by the labor migrants from the republics of Central Asia and the South Caucasus (in descending order of the number of incomers - from Tajikistan, Kyrgyzstan, Azerbaijan, Kazakhstan, Armenia, and Uzbekistan), Ukraine and non-CIS countries (mainly China and North Korea). In addition, migrants, along with the work in transportation companies and in construction industry, are actively engaged in various types of small businesses, such as trade, foodservice industry, growing vegetables and fruit. In the 1990s, a lot of immigrants from the republics of the former Soviet Union arrived to the Territory. According to the Decree of the Government of the Russian Federation, signed by D.A. Medvedev on 22 July 2014, 1935 Ukrainian refugees were sent to the Territory. The decree was published on the website of the Government of the Russian Federation. 3041 Ukrainian citizens, who were forced to leave their homeland, applied to the Russian Federal Migration Service of the Krasnoyarsk Territory for granting temporary asylum, what was reported by the press service of the institution on 14 October 2014. "Those who have decided to cast their lot with Russia applied for participation in the state program of assistance to the voluntary resettlement of compatriots living abroad. As of today, the regional migration office received 326 such applications", - they said in the FMS. In total, 2 995 Ukrainian citizens, including 792 children, were officially granted temporary asylum in the Russian Federation for the period of one year. From the total number of Ukrainians who were granted temporary asylum in the Territory, only 30 later withdrew from the migration registration. Some of them moved from the Krasnoyarsk Territory to the other subjects of the Russian Federation and five of them returned home (More than..., 2016) . As we can see, about 10\% of those, who arrived from Ukraine, decided to stay in the Territory for a long period. The rest, as a rule, are waiting for the end of the conflict in their homeland. A similar situation with account of the deteriorating economic situation in the country in general and the region in particular, may subsequently cause specific problems in interethnic relations in the Territory.

Along with that, the Krasnoyarsk Territory has always been multiethnic and multicultural region. According to the 1989 census, the most numerous ethnic groups in the region, in the descending order, were Russians, Ukrainians, Khakas (at that time the Republic of Khakassia was a part of the Territory), Germans, Tatars, Belarusians, Chuvash, Mordvins, Azerbaijanis, Mari, Latvians, Estonians, Bashkirs, Dolgan, Udmurts, Moldavians, Uzbeks, Evenks, Poles, Kazakhs, Jews, Lithuanians, Armenians, etc., 124 nationalities in total. Even larger number of nationalities was recorded in the two subsequent censuses, but at the same time the number of representatives of some ethnic groups in the Krasnoyarsk Territory changed. According to the census conducted in 2002, representatives of 157 nationalities were recorded in the Krasnoyarsk Territory and 164 nationalities in 2010; the number of the representatives of 64 nationalities is more than 100 people. 
In general, in the 1990s there were quite serious changes of the ethnic composition in the Krasnoyarsk Territory. These changes were caused by the sharp rise of national consciousness and the sovereign states formation in the postSoviet space, increased migratory activity of the population and the crisis of demographic development. The proportion of non-Russian population in the region significantly decreased, from $12.4 \%$ in 1989 to $11.0 \%$ in 2002 and $8.7 \%$ in 2010 . Only in the period between the censuses of 1989 and 2002 the number of Russian population declined for 13 years by 22.3 thousand people, or $0.5 \%$, while the "losses" of the national community during this period were 50.3 thousand people, or $13.3 \%$. The number and proportion of ethnic groups within the ethnic community of the Territory notably changed. The number of the long-time (for the Krasnoyarsk Territory) diaspora population decreased due to decrease in natural growth, migration loss, cultural-integration and assimilation processes. Thus, from 1989 to 2010 the number of Shors decreased by 9.7 times, Komis by 5 times, Finns by 3.6 times, Mordvins by 3.4 times, Belarusians by 3.4 times, Kalmyks by 3.3 times, Poles and Jews by 3.2 times, Ukrainians by 3.1 times, Latvians by 2.9 times, Lithuanians by 2.8 times, Estonians and Udmurts by 2.6 times, Germans and Chuvash by 2.4 times, Mari by 2.3 times, Altaians and Bulgarians by 2.1 times, Bashkirs, Kazakhs, Moldavians and Greeks by 1.9 times, Georgians by 1.7 times, Tatars and Turkmens by 1.6 times, etc. (see Table 6).

Unlike long-time nationalities of the Krasnoyarsk Territory, the diasporas of Caucasus, Central and South-East Asia significantly increased their number in the region through the increased birth rate and active migration: Tajiks by 4.6 times, Chinese by 4.4 times, Kyrgyz by 3.3 times, Lezgians by 2.3 times, Azerbaijanis by 2 times, Armenians by 3.2 times, Uzbeks by 1.4 times. If, according to the 1989 census, 2 Vietnamese lived in the Territory, in 2010 the number was 181 people.

As a positive trend, stabilization in the population of a number of indigenous smallnumbered peoples of the North with a slight tendency to growth can be noted in the Territory. In the case of Dolgans it was $6.4 \%$, Nenets $37 \%$. The number of Kets and Evenks remained stable in the period between the censuses. Enets (increase by 1.8 times), Nganasans (decrease by 1.4 times) and Selkups - decrease by 1.3 times are the exceptions. The growth of northern Aboriginal population in difficult socio-economic conditions is determined by the relatively high birth rate, as well as active self-identification of métis in referring themselves to the 65 nationalities of the North. Their expectations are associated with the hope of targeted social support from the state through the adoption and implementation of federal and regional target programmes. It is indicative that urbanization processes are rapidly developing among ethnic minorities. Migrants, arriving to the Territory, try to stay in the major cities, creating enclaves based on ethnicity, while the number of long-time peoples who live in the village is rapidly decreasing due to migration beyond the Territory and "aging" population. In general, the non-Russian population lives in all the towns and districts of the Krasnoyarsk Territory. In more than a half of them the share of representatives of non-Russian nationalities does not exceed $10 \%$, in 23 towns and districts this figure ranges from 10 to $20 \%$. However, in Norilsk and some northern areas, this figure exceeds 30\% (Nemirovskiy et al., 2010).

In addition, in 2010 a sharp increase in the number of individuals who did not indicate their nationality in the census draws attention. This can be explained by the fact that some respondents don't want to indicate their nationality in the case of belonging to migrants' minorities, especially 
Table 6. Number of Representatives of Different Ethnic Groups in Population of the Krasnoyarsk Territory (according to 1989, 2002 and 2010 population censuses data, people)

\begin{tabular}{|c|c|c|c|}
\hline & 1989 & 2002 & 2010 \\
\hline 1 & 2 & 3 & 4 \\
\hline Russians & 3110972 & 2638281 & 2490730 \\
\hline Ukranians & 118763 & 68662 & 38012 \\
\hline Tatars & 54052 & 44382 & 34828 \\
\hline Germans & 54254 & 36850 & 22363 \\
\hline Azerbaijanis & 8327 & 19447 & 16341 \\
\hline Chuvash & 26865 & 16859 & 11036 \\
\hline Armenians & 3375 & 10807 & 10677 \\
\hline Belarusians & 33856 & 18149 & 9900 \\
\hline Kyrgyz & 2547 & 3876 & 8423 \\
\hline Uzbeks & 4761 & 2778 & 6434 \\
\hline Tajiks & 1377 & 3507 & 6304 \\
\hline Dolgans & 5460 & 5805 & 5810 \\
\hline Evenks & 4382 & 4632 & 4372 \\
\hline Mordvins & 14873 & 7526 & 4295 \\
\hline Khakass & 69325 & 4489 & 4102 \\
\hline Nenets & 2661 & 3188 & 3633 \\
\hline Mari & 7748 & 5104 & 3314 \\
\hline Bashkirs & 5485 & 3874 & 2955 \\
\hline Tuvinians & 2570 & 1492 & 2939 \\
\hline Lezgians & 1215 & 2199 & 2800 \\
\hline Moldavians & 5101 & 3803 & 2749 \\
\hline Chinese & 554 & 665 & 2439 \\
\hline Estonians & 6061 & 4104 & 2346 \\
\hline Latvians & 6414 & 3747 & 2189 \\
\hline Udmurts & 5240 & 3250 & 2026 \\
\hline Kazakhs & 3827 & 2613 & 1970 \\
\hline Gypsies & 2358 & 1992 & 1901 \\
\hline Ossetians & 1957 & 1754 & 1493 \\
\hline Yakuts & 1778 & 1368 & 1468 \\
\hline Georgians & 2301 & 1918 & 1336 \\
\hline Lithuanians & 3520 & 2029 & 1277 \\
\hline Poles & 4056 & 2519 & 1268 \\
\hline Jews & 3620 & 1798 & 1147 \\
\hline Buryats & 1463 & 1051 & 1051 \\
\hline Koreans & 1275 & 1207 & 1029 \\
\hline Kets & 994 & 1189 & 957 \\
\hline Nogais & 175 & 380 & 950 \\
\hline Nganasans & 1128 & 811 & 807 \\
\hline Chechens & 1114 & 999 & 685 \\
\hline
\end{tabular}


Continuation Table 6

\begin{tabular}{|c|c|c|c|}
\hline 1 & 2 & 3 & 4 \\
\hline Greeks & 1179 & 930 & 635 \\
\hline Kumycs & 486 & 567 & 596 \\
\hline Latgalians & no data & 807 & 577 \\
\hline Avars & 742 & 636 & 512 \\
\hline Turkmens & 767 & 280 & 477 \\
\hline Ingushes & 481 & 496 & 448 \\
\hline Cossacks & no data & 288 & 391 \\
\hline Laks & 233 & 345 & 358 \\
\hline Bulgarians & 659 & 564 & 317 \\
\hline Dargins & 318 & 367 & 316 \\
\hline Komi-Permyaks & 996 & 648 & 308 \\
\hline Finns & 1076 & 635 & 303 \\
\hline Tabasarans & 164 & 221 & 299 \\
\hline Selkups & 367 & 412 & 281 \\
\hline Gagauzes & 197 & 370 & 276 \\
\hline Enets & 121 & 213 & 221 \\
\hline Kalmyks & 694 & 322 & 213 \\
\hline Yazidis & no data & 217 & 206 \\
\hline Kabardians & 422 & 268 & 190 \\
\hline Vietnamese & 2 & 112 & 181 \\
\hline Shors & 1560 & 201 & 161 \\
\hline Komis & 788 & 353 & 159 \\
\hline Altaians & 316 & 215 & 147 \\
\hline Chulyms & no data & 159 & 145 \\
\hline Uyghurs & 104 & 108 & 115 \\
\hline $\begin{array}{l}\text { Individuals, who didn't indicate their } \\
\text { ethnic background }\end{array}$ & 4472 & 15822 & 100621 \\
\hline
\end{tabular}

Note: only ethnic groups with the population of more than 1000 people at the moment of 2010 census are represented in the Table.

Source: Census data of the regions of Russia in 1989, 2002 and 2010. The Russian Federal Statistical Service. The data are available at: http://demoscope.ru/weekly/ssp/rus_nac_89.php http://www.perepis2002.ru/index.html?id=17 http://www.gks. $\mathrm{ru} /$ free_doc/new_site/perepis2010/croc/perepis_itogi1612.htm (Accessed 10 January 2016).

in the case of absence of registration at the place of residence and the necessary documents for employment.

According to the surveys, conducted in the period from 2010 to 2014, opinions of the Territory population about the relationships between migrants and the indigenous population became more formed: for example, 9.4\% less respondents find it difficult to assess the relationship between newcomers and residents of the Krasnoyarsk Territory than in 2010 (Table 7).

Along with that, a relatively low amount of responses "Tense relationships, fights are frequent, police are called" has doubled, 3.0 and $6.5 \%$. The number of respondents who chose the variant "Relationships are bumpy, tensions 
Table 7. Distribution of Answers to the Question "If You Know About the Life of Newcomers (Migrants, Refugees, etc.) in Your Region, Give Your Opinion: Whether They Have Good Relationships With the Local Population?" (\% from the number of respondents)

\begin{tabular}{|l|c|c|c|}
\hline \multicolumn{1}{|c|}{ Variants of answers } & 2010 & 2012 & 2014 \\
\hline They have stable good relationships & 16,8 & 16,0 & 15,6 \\
\hline In general, the relationships are good, but misunderstandings happen & 36,5 & 38,6 & 38,6 \\
\hline Relationships are bumpy, tensions are frequent & 12,7 & 13,7 & 16,7 \\
\hline Tense relationships, fights are frequent, police are called & 3,0 & 4,0 & 6,5 \\
\hline Local population and newcomers practically do not have relationships & 3,8 & 5,2 & 4,9 \\
\hline Cannot say & 27,2 & 22,5 & 17,8 \\
\hline
\end{tabular}

are frequent" has also slightly increased, 12.7 and $16.7 \%$. Now it has exceeded the number of the Territory residents, who have the opinion that "They have stable good relationships", 16.8 and $15.6 \%$. Most respondents continue to believe that "In general, the relationships are good, but misunderstandings happen”, 36.5 and $38.0 \%$.

Nevertheless, it is important to note, that in general, more than a half of the Territory residents indicate of quite positive relationships with migrants $-54.2 \%$ (the variant of answer "They have stable good relationships" was chosen by $15.6 \%$ of the respondents $+38.6 \%$ of the respondents, according to whom "In general, the relationships are good, but misunderstandings happen").

\section{Resume}

The conducted research has shown that in the period of 2010 - 2014 emotional attractiveness of socio-cultural space of the Territory has generally increased that, in fact, should have a positive impact on migratory population growth. However, financial and economic crisis that has intensified in the recent years could have a negative impact on cultural attractiveness of life in Siberia and increase migration outflow from the Krasnoyarsk Territory.

Currently, intensification of alienation of migrants from other cultures in the Siberian region has been revealed. Accordingly, it is difficult to talk about complete understanding between the local population and migrants in the Krasnoyarsk Territory. But, according to surveys, currently there is no serious tension in inter-ethnic and inter-cultural relationships between resident population and newcomers. This is largely determined by the mentality and cultural traditions of the inhabitants of Siberia, which population has long been formed due to newcomers, forced and voluntary migrants: refugees, exiles, labor migrants, etc. Accordingly, historically, it has been characterized by multiethnic composition, and socio-cultural space of the region had pronounced multicultural characteristics. However, infringement of the long existed in the Territory tradition of multiculturalism, connected with changing of the traditional system of values and increased atomization of the population, is possible in the future.

\section{References}

Chaban, S.V. (2006). Socio-cultural Identification and Integration of Migrants in the Contemporary Russia. A Candidate's Thesis on Sociology. Rostov-on-Don, $161 \mathrm{p}$.

$$
-865-
$$


Zamarayeva, Ju.S. (2011). Relation of the Migrant and the Receiving Environment as a Phenomenon of the Krasnoyarsk Territory Modern Culture (Association Experiment Results Based on the Methodology "Serial Thematic Associations"), In Journal of Siberian Federal University. Humanities \& Social Sciences, 6 (4), 805-815.

Koptseva, N.P., Bakhova, N.A., Zamaraeva, J.S., Kirko V.I. (2012). The Problem of Social and Cultural Studies in Contemporary Human Sciences, In Contemporary Issues of Science and Education, (3). Available at: www.science-education.ru/103-6183 (accessed 10 January 2016)

Koptseva, N.P., Zamaraeva, Y.S., Kirko, V.I. (2015) Ethnic Migration in Central Siberia (Krasnoyarsk Territory), In Mitteilungen Klosterneuburg, 65(2), 2-20.

Migration of the Population in the Krasnoyarsk Territory in 2014. Press-release of 23.03.2015. Krasnoyarsk State Statistical Office. Available at: http:/www.krasstat.gks.ru/wps/wcm/connect/ rosstat_ts/krasstat/ru/news/rss/fdcd220047belc2a9428b4ed3bc4492f (accessed 10 January 2016)

Migrations and Diasporas in the Socio-cultural, Political and Economic Space of Siberia. The Turn of the $19^{\text {th }}-20^{\text {th }}$ and the $20^{\text {th }}-21^{\text {st }}$ Centuries (2010). Ed. by V.I. Dyatlov, Irkutsk, $640 \mathrm{p}$.

More than 3 Thousand Ukrainian Refugees Have Been Registered in the Krasnoyarsk Territory, In Online newspaper Newslab.ru. 14 October 2014. Available at: http://newslab.ru/news/615460 (accessed 10 January 2016)

Mukomel, V.I. (2006). Socio-cultural Factors for Migration Policy in the Post-Soviet Russia. Doctoral Thesis on Sociology, Moscow, 398 p.

Nemirovskiy, V.G., Nemirovskaya A.V. Socio-cultural Portrait of the Krasnoyarsk Territory. Krasnoyarsk, Siberian Law Institute of the Ministry of Internal Affairs of the Russian Federation, 2010. 264 p.

Nemirovskiy, V.G., Nemirovskaya, A.V. (2014) Socio-cultural Processes in Siberian Region (The Krasnoyarsk Territory in 2010 - 2014). Krasnoyarsk, Siberian Federal University, 244 p.

Pistryakova S.A. (2008). Socio-cultural Aspects of Integration of Migrants of Other Nationalities in the Russian Society. The Alternatives to Migration Strategy for Russia, In Immigration Issues: Tolerance against Xenophobia and Discrimination. Moscow, 6-34.

Popkov, Yu.V., Tygashev, E.A. (2014). Ethnosocial Processes in Siberia: Modern Reality and Actual Issues of Ethnosocial Policies, In New Research of Tuva, (3), 129-146. Available at: http://www. tuva.asia/journal/issue_23/7330-popkov-tyugashev.html (accessed 10 January 2016).

Solodova, S.G. (2010). Muslim Migrants - Attitudes and Practices in the Context of Russian Society, In The Bulletin of Novosibirsk State University, 8(3), 88-94.

The Methodological Recommendations on the Organization and Conducting Empirical Research in The Regions of Russia: Socio-cultural Portraits of Regions in the Russia-wide Context (2009), Ed. by N.I. Lapin, L.A. Belyaeva. Moscow, 796-807. 


\title{
Социокультурные особенности динамики
}

\section{миграционных процессов}

в Центральной Сибири

(на материалах исследований

в Красноярском крае в 2010-2014 гг.)

\author{
В.Г. Немировский ${ }^{a}$, А.В. Немировская ${ }^{\sigma}$ \\ Сибирский федеральный университет \\ Россия, 660041, Красноярск, пр. Свободный, 79 \\ Национальный исследовательский университет \\ «Высшая школа экономики» \\ Россия, 101000, Москва, ул. Мясниикая, 20
}

В статье рассматриваются соииокультурные особенности миграционных процессов в одном из крупнейших регионов Сибири - Красноярском крае. Работа опирается на данные опросов населения Красноярского края, проведённых методом формализованного интервью по методике «Социокультурный портрет региона» в 2010, 2012 и 2014 г2. Раскрыты динамика эмочионального отномения жителей края в контексте их миграчионных настроений, мнения о качестве жизни в Красноярском крае по сравнению с другими регионами Сибири, о культурных аспектах привлекательности (и непривлекательности) жизни в данном регионе. Выявлено некоторое усиление негативного отношения населения Красноярского края к прибывающим мигрантам иных национальностей, связанное главным образом с культурнымм антагонизмом. Эта социокультурная ситуация всё более ярко проявляется на поведенческом уровне. Выдвигается предположение о возможном нарушении в будущем традиционно существовавщей в регионе традиции мультикультурности.

Ключевые слова: социокультурные процессы, сочиокультурные представления, культурная привлекательность региона, социокультурные аспекты миграции, мультикультурность.

Научная специальность: 22.00.00 - социологические науки. 